\title{
Ambivalence: The Resiliency of Legal Culture in the United States
}

\section{Judith Resnik*}

Law schools tell a pretty cheerful story, which goes something like this: In 1789, the United States came into being, and its constitution-the Constitution-has framed and constrained legal developments ever since. While there have been a few bumps along the way (such as slavery, the Civil War, and the race riots of the twentieth century), we (as in "We the People") have persevered. If it has not all come out alright yet, it will, soon; all that is needed is patience and constitutional faith. ${ }^{1}$

The emergence of a range of commentaries-critical legal studies, feminism, critical race theory - has not made much of a dent in the basic story, as it is retold annually in the law school classroom. While some participants in this Symposium on Civic and Legal Education bemoan the fragmentation of the legal scholarly enterprise, ${ }^{2}$ they miss the stunning stability of the classroom.

The invulnerability of the classroom to radical critique relies on at least three factors. First, law professors tend to teach what they themselves have been taught. Most accept that the traditional "Cases and Comments on ..." are the subject matter of particular courses. ${ }^{3}$ Few of the recent editions of these books, in turn, revise in fundamental ways the framing of basic

* Judith Resnik, All rights reserved. Orrin B. Evans Professor of Law, University of Southern California Law Center. My thanks to Barbara Babcock, Christine Carr, Kimberlé Crenshaw, Denny Curtis, Veronica Gentilli, Carolyn Heilbrun, Deborah Hensler, Barbara Herman, Vicki Jackson, Angela Johnson, Gladys Kessler, Peggy Radin, Deborah Rhode, Vicki Shultz, Barrie Thorne, and Catharine Wells for joining me in thinking about these issues.

1. While this story is evidently not peculiar to law schools, but pervades United States' culture and liberal ideology as well, it is a story of special import to legal education. Further, as detailed by Deborah Rhode, the law reform concerns that permeate some classrooms reinforce the basic claim of the rightness of the legal order. See Deborah L. Rhode, Missing Questions. Feminist Perspectives on Legal Education, 45 STAN. L. REV. 1547, 1548-49 (1993).

2. See Larry Alexander, What We Do, and Why We Do It, 45 STAN. L. Rev. 1885 (1993); Richard A. Epstein, Legal Education and the Politics of Exclusion, 45 STAN. L. Rev. 1607 (1993); Richard A. Posner, Legal Scholarship Today, 45 STAN. L. REv. 1647 (1993).

3. In 1980, I attended an intensive workshop, designed by the American Association of Law Schools (AALS) to discuss the teaching of civil procedure. The participants came from law schools across the country, and all taught procedure. One of the authors of a then-leading casebook announced in his talk: "If you don't teach Hanson v. Denckla, you don't teach civil procedure."

For those readers who have been taught by "illegitimate" procedure teachers, such as myself, who neither ask students to read nor consider that case, Hanson v. Denckla, 357 U.S. 235 (1958), is one of dozens in which the Supreme Court details the rules governing the jurisdiction of state courts over litigants outside their geographic boundaries. 
courses. ${ }^{4}$ Indeed, despite the emergence over the past decade of interest in "law and literature" and of the call for stories and narratives, few within the legal academy have drawn from contemporary literary criticism what I take to be a central message for law: to question what materials constitute the canon. ${ }^{5}$

Generations of law students read and reread the same Supreme Court cases, and while some of the old cases are replaced by discussions of recent

4. The histories of courses that I teach, procedure and federal courts, are my primary examples. Let me offer here a capsule summary of the teaching materials for "Federal Courts" or "Federal Jurisdiction," a class concerned with the allocation of power among the federal courts, Congress, and the Executive, and between the federal and state court systems, and typically taught to upper division students.

In 1928, Felix Frankfurter and James Landis wrote a book, Felix Frankfurter \& JAMES M. LANDIS, The Business of the SUPReme Court: A STUdy in THE Federal JUdicial System (1928), which provided an overview of the history and functioning of the federal courts. Soon thereafter, Frankfurter, joined first by Wilber G. Katz and later by Harry Schulman, authored a text designed for students. Frankfurter and his collaborators aspired to distinguish their interest from earlier federal "practice" books by considering issues they claimed appropriate for academic study. See Felix Frankfurter \& Wilber G. Katz, Cases and Other authorities on Federal JURISDICTION AND ProcedURE at v (1931); see also Felix FrankfurTer \& HARRY SHULMAN, CASes and Other Authorities on Federal Jurisdiction and Procedure (rev. ed. 1937). The authors addressed issues such as the case and controversy requirements of Article III of the Constitution, the power of federal courts to make common law, and the allocation of jurisdiction between state and federal courts.

That the questions explored by Frankfurter, Landis, Katz, and Shulman are familiar to today's teachers of the subject is not a matter of chance. The contemporary conception of the course derives in large part from that of Frankfurter and his colleagues, whose views shaped much of the content of

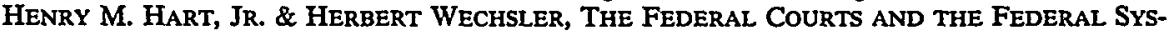
TEM (1953). Not only is the current edition of that book similar to the 1953 version, but most other teaching texts have followed its choice of subject matter, albeit often in fewer pages and with a less encyclopedic tone. See Paul M. Bator, Daniel J. Meltzer, Paul J. Mishkin \& David L. Shapiro, Hart and Wechsler's The Federal Courts and the Federal System (3d ed. 1988); see also David P. CuRrie, Federal Courts: CASEs and Materials (3d ed. 1982); Howard P. Fink \& Mark V. Tushnet, Federal Jurisdiction: Policy and Practice (2d ed. 1987); Peter W. Low \& John Calvin JefFries, JR., Federal Courts aNd the LAw of Federal-State Relations (2d ed. 1989); Martin H. Redish, Federal Courts: Cases, ComMENTS AND QUESTIONS (2d ed. 1989). The fidelity of the "new" Hart and Wechsler to the "old" Hart and Wechsler is explored in Akhil Reed Amar, Law Story, 102 HARv. L. Rev. 688 (1989) (reviewing BATOR ET AL. supra).

My colleagues who teach other basic and advanced courses tell me that their courses are similarly loyal to earlier conceptions. One area that has received detailed consideration is that of criminal law; a group of scholars have criticized the structure and content of the criminal law curriculum. See Nancy S. Erickson, Final Report: "Sex Bias in the Teaching of Criminal Law," 42 RUTGERS L. REv. 309 (1990). Others have noted that, even when casebooks are changed in light of such criticisms, teachers may resist such innovation. In his essay, On Teaching Rape: Reasons, Risks, and Rewards, 102 YALE L.J. 481 (1992), James J. Tomkovicz explained that, although criminal casebooks now include materials on rape, professors loyal to coverage of traditionally-taught issues sometimes skip the topic, in part from discomfort and in part because they do not know what to delete when new issues are added. Id. at 483. Susan Estrich's Teaching Rape Law, 102 YALE L.J. 509 (1992), attempts to reassure the anxious that, while teaching rape law is "a challenge," its intellectual and conceptual demands make it the best kind of topic for classroom teaching. Id. at 519-20.

Efforts are currently underway to press for more revisions of the canon. In May of 1993, the Society of American Law Teachers convened a conference, "Integrating Class, Disability, Gender, Race, and Sexual Orientation into Our Teaching and Course Material."

5. Instead, much of "law and literature" is either about law in literature or law as literature. See Carolyn Heilbrun \& Judith Resnik, Convergences: Law, Literature, and Feminism, 99 YALE L.J. 1913, 1936-42 (1990). 
problems and changes in doctrine, the outlines and topics remain undisturbed. While "supplemental" materials are sometimes added, little is subtracted from the basic story. What is reiterated is the story "already read,"6 a generally upbeat tale that depends on not mentioning many aspects of the United States' legal system - the centrality of slavery, the conquest of Indian tribes and the current a-constitutional relationship between the United States government and the tribes, the oppression of racial and ethnic groups and of women, ${ }^{7}$ and the effects of poverty on regimes of property-based rights, inter alia. ${ }^{8}$

A second factor is the conservative (in the sense of preserving) power of the law and economics movement, which is heavily financed by conservative (in the political sense) foundations and which dominates many scholarly fields, with tort law being a prime example. ${ }^{9}$ Funding from the Olin Foundation, the Scaife charities, and other institutions has supported fellowships for young scholars to write in law and economics and for sitting judges to attend seminars on law and economics. ${ }^{10}$ Much of the scholarship and commentary produced thus far not only seeks to justify the status quo ${ }^{11}$ but is also hostile to various forms of critical scholarship. Law and economics adherents sometimes characterize such work as lacking the intellectual strength found in the economic approach. ${ }^{12}$ Thus, during the very same decade in which critical commentary has emerged in force, the law and eco-

6. See Annette Kolodny, Dancing Through the Minefield: Some Observations on the Theory, Practice, and Politics of a Feminist Literary Criticism, in THE NEW FEMINIST CRITICISM: EsSAYS ON WOMEN, LITERATURE, AND THEORY 144, 154-55 (Elaine Showalter ed., 1985).

7. For discussions of some of the implications of including the sovereignty of Indian tribes and the status of women in courses on the federal courts, see Judith Resnik, Dependent Sovereigns: Indian Tribes, States, and the Federal Courts, 56 U. CHI. L. REv. 671 (1989); Judith Resnik, "Naturally" Without Gender: Women, Jurisdiction, and the Federal Courts, 66 N.Y.U. L. REv. 1682 (1991).

8. That the Depression is not usually mentioned as a bump along the constitutional path illustrates the absence of consciousness of class in the story and explains in part why poverty has not been understood as the basis for a federal constitutional claim. See, e.g. San Antonio Indep. Sch. Dist. v. Rodriguez, 411 U.S. 1 (1973) (rejecting an equal protection challenge to the funding of public schools through local property taxes).

9. See, e.g., 1 AMERICAN LAW INSTITUTE, REPORTERS' STUDY: ENTERPRISE RESPONSIBILITY For Personal INJURy: THE INSTITUTIONAL Framework at v-vi (1991) (listing the scholars serving as reporters, contributors, and advisers for this work).

10. Henry G. Manne, Dean of George Mason University School of Law, for example, coordinates seminars sponsored by that school's Law and Economics Center, and ran such study sessions for many years before moving to George Mason.

11. The methods by which power is accrued include the choice of words and the deployment of models. For example, naming an approach "rational choice" theory implies the "irrationality" of other approaches. Similariy, the notion of "statistical discrimination"- that said to be produced by a "rational" discriminator rather than one animated by impermissible motives-ensures that the discussion of discrimination focuses on the experiences and perspectives of the discriminator, rather than those of the victim.

12. As Robert Ellickson, self-identified as a law and economics scholar, puts it: "To exaggerate only a little, the law-and-economics scholars believe that the law-and-society group is deficient in both sophistication and rigor ...." RoBERT C. ElLICKSON, ORDER WITHOUT LAW: How NEIGHBORS SETTLE DISPUTES 7 (1991). Indeed, illustrative of that view, Ellickson describes his work as "Bringing Theory to Law-and-Society Scholarship." Id. at 6. Ellickson also views law and society proponents as skeptical of law and economics scholars' understanding of "reality" and concern about "humanity." Id. at 7. 
nomics movement has been rich with its own economic resources, and the dominant "voice" (to borrow a phrase not often heard within that scholarly community) of that scholarship has lent support to the cheerful tale of the United States polity. ${ }^{13}$

Third, and simply put, it is hard for professors to stand up before students and tell them of the failures of the discipline, law, to which we who teach have devoted ourselves and to which so many of us and them have come with such high hopes. (Were one coming from or speaking to many other segments of the public, that message would not be as difficult to convey, nor would it be news.) It is hard not only because some students do not want to hear it, but also because I-a white, female law teacher-am ambivalent about how damning I want to be.

The resiliency of legal culture to critical attack-and the fact that it is hard even to hear the criticism-is evident not only in the classrooms of law schools. One also finds such resiliency in courthouses around the nation. A movement within the courts parallels the critical commentaries of law that have emerged in the legal community over the past decade. Much of this work has taken the form of "gender bias task forces" and "race and ethnic bias task forces." Since the 1980s, some thirty jurisdictions have authorized projects to explore how courts, as decisionmakers, employers, and institutions, are affected by bias based on gender, race, and ethnicity. ${ }^{14}$

The Ninth Circuit Gender Bias Task Force, for example, is the first within the federal system to ask the question of what effects gender has on its courts and has broadened the scope of the inquiry in several respects. ${ }^{15}$ This task force work comes after a decade of similar projects in the state courts and is deeply indebted to them. ${ }^{16}$ The Ninth Circuit's conclusions fit comfortably with those of the now more than thirty published reports on either gender bias or race and ethnic bias in the courts. ${ }^{17}$ The uniformity is impres-

13. Few of the scholars critical of current regimes find sustained support from conservative foundations. Critiques are funded by other means. See, e.g., Ian Ayres, Fair Driving: Gender and Race Discrimination in Retail Car Negotiations, 104 HARv. L. Rev. 817 (1991) (using research done by Ayres as an American Bar Foundation Research Fellow).

14. Illustrative is the publication, in this volume of the Stanford Law Review, of the Executive Summary of the Preliminary Report of the Ninth Circuit Gender Bias Task Force (of which I am a member) that was delivered to the $\mathbf{4 5 0}$ judges and lawyers at the Ninth Circuit Judicial Conference in August 1992. See Ninth Circuit Task Force on Gender Bias, Executive Summary of the Preliminary Report of the Ninth Circuit Task Force on Gender Bias, 45 STAN. L. REv. 2153 (1993).

15. The report is the first to consider the effects of gender on immigration, bankruptcy, federal benefits, and federal Indian law. Further, because the Ninth Circuit encompasses nine states, the report also draws on survey data from judges and practitioners in each of the districts within the circuit. Id.

16. See generally Lynn Hecht Schafran, Gender Bias in the Courts: An Emerging Focus for Judicial Reform, 1989 ARIZ. ST. L.J. 237 (1989) (reviewing the achievements); Norma J. Wikler, Water on Stone: A Perspective on the Movement to Eliminate Gender Bias in the Courts, STATE CT. J., Summer 1989, at 3 (analyzing the history of the gender bias task force movement).

17. For a list of reports relied on in this essay, see Appendix A. I reviewed 24 jurisdictions (22 states, the District of Columbia, and the Ninth Circuit) that have published a total of 33 reports. Six jurisdictions (the District of Columbia, Florida, Michigan, New Jersey, New York, and Washington) have published both gender and race and ethnic bias reports. The National Center for State Courts (NCSC) is a clearinghouse for information about such projects. See NCSC, Proceedings of the Na- 
sive, as each jurisdiction finds anew what others have found before: that courts do not deliver on the promise of equal treatment. The cheerful tale repeated in classrooms is thus challenged not only from within the allegedly sheltered towers of academia but from the world of practice as well.

At their core, these task forces on bias in the courts are fabulously radical, have actually been successful in engendering some change, ${ }^{18}$ and yet are absorbed as if the reports did not say what they do. Radical, because all of these efforts are taken on by court systems themselves, as chief judges and other senior officials of the legal profession break through the constitutional story and actually ask: Do we discriminate? How? Against whom? In general? In pervasive and diffuse ways?

How could such questions be called "radical"? Recall that the Supreme Court of the United States, when asked in 1987 in McCleskey v. Kemp 19 to consider whether Georgia had imposed the death sentence in a generally racially-discriminatory fashion, ${ }^{20}$ declined the broad inquiry. The Court said that, while it was prepared to look individually at a particular person's claim that he or she had been sentenced to death because of racial prejudice, the Court could not entertain a claim that the administration of the death penalty as a whole violated the Equal Protection Clause. ${ }^{21}$

tional Conference on Gender Bias in the Courts (Dixie K. Knoebel \& Marilyn McCoy Roberts eds., 1990).

18. See text accompanying notes $40-45$ infra.

19. 481 U.S. 279 (1987).

20. Warren McCleskey's constitutional claim relied in large measure on a statistical study (authored by Professors David Baldus, Charles Pulaski, and George Woodworth) which reviewed 2000 murder cases in Georgia during the 1970s. For discussion of the study and a critique of the McCleskey decision, see David C. Baldus, George G. Woodworth \& Charles A. Pulaski, Jr., Equal Justice and the Death Penalty: A Legal and Empirical ANalysis (1990). The data indicated that "black defendants, such as McCleskey, who kill white victims have the greatest likelihood of receiving the death penalty." McCleskey, 481 U.S. at 287. The Court held that "the Baldus study does not demonstrate a constitutionally significant risk of racial bias affecting the Georgia capital sentencing process." Id. at 313.

The four dissenting Justices-Brennan, Marshall, Blackmun, and Stevens-disagreed. In their view, the data meant that

[D]efendants charged with killing white victims in Georgia are 4.3 times as likely to be sentenced to death as defendants charged with killing blacks. . . . In addition, . . 6 of every 11 defendants convicted of killing a white person would not have received the death penalty if their victims had been black.... [C]ases involving black defendants and white victims are more likely to result in a death sentence than cases featuring any other racial combination of defendant and victim.... [T] here was a significant chance that race would play a prominent role in determining if [McCleskey] lived or died.

Id. at 321 (Brennan, J., dissenting) (citations omitted). Reading the statistical data through the lens of "[h]istory and its continuing legacy," as well as "social experience," the dissent concluded that McCleskey had demonstrated that the imposition of the death penalty was unconstitutional. $I d$. at 334-35.

On September 25, 1991, after Mr. McCleskey had argued unsuccessfully in subsequent proceedings that his punishment was unconstitutional for other reasons (see McCleskey v. Zant, $111 \mathrm{~S}$. Ct. 1454 (1991)), Georgia authorities executed him. See Peter Applebome, Georgia Inmate Is Executed After 'Chaotic' Legal Move, N.Y. TIMES, Sept. 26, 1991, at A18; see also Sawyer v. Whitley, 112 S. C. 2514, 2527 (1992) (Blackmun, J., concurring in the judgment) (discussing Mr. McCleskey).

21. As Justice Powell, for the Court, interpreted the Equal Protection Clause, a claimant had to show that "decisionmakers in his case acted with discriminatory purpose." McCleskey v. Kemp, 481 U.S. at 292. A defendant could not rely on a claim of discrimination that 
The Court's discussion of "each jury" as "unique," making assessments "according to the characteristics of the individual defendant and the facts of the particular capital offense,"22 both relied on and reaffirmed the cheerful constitutional tale. While "the history of racial discrimination in this country is undeniable"23 (there have, after all, been bumps along the road), claims of prejudice relying on "historical evidence"-stemming from Georgia's laws at the time of the Civil War-could not serve as evidence relevant to today's injuries, which occur in a world presumed not to be burdened by that history.

As the majority explained, taking on the general issue of racism in death penalties would implicate the general issue of racism in all kinds of sentencing penalties. ${ }^{24}$ In this conclusion lurks a "so what?"-why not explore the general issue of racism in all kinds of sentencing penalties? What is instructive about the opinion is its unself-conscious explanation of why such a fundamental challenge was beyond comprehension. ${ }^{25}$ In the words of the Court:

[I]f we accepted McCleskey's claim that racial bias has impermissibly tainted the capital sentencing decision, we could soon be faced with similar claims as to other types of penalty. Moreover, the claim that his sentence rests on the irrelevant factor of race easily could be extended to apply to claims based on unexplained discrepancies that correlate to membership in other minority groups, and even to gender. ${ }^{26}$

Task forces on gender, racial, and ethnic bias do exactly what the Supreme Court refused to do: They ask the forbidden questions. Unlike the Supreme Court majority in McCleskey, they seem not to fear "too much justice" but too little. ${ }^{27}$ These task force projects are not only radical in their inquiry, but also in their frequent and consistent answer: that despite their emblems of "equal justice under law," courts are a venue of discrimination-against women in general, against people of color in general, against women of color in distinct ways, against not only litigants but also against

[i]n its broadest form, ... extends to every actor in the Georgia capital sentencing process, from the prosecutor who sought the death penalty and the jury that imposed the sentence, to the State itself that enacted the capital punishment statute and allows it to remain in Id. effect despite its allegedly discriminatory application.

22. Id. at 294.

23. Id. at $298 \mathrm{n} .20$.

24. As the Court put it: "McCleskey challenges decisions at the heart of the State's criminal justice system." Id. at 297.

25. This case provides other insights about the nature of racial, ethnic, and gender bias. For example, as Stephen Carter and Randall Kennedy have both noted, the Court did not even contemplate the implications of the Baldus data for black victims, underprotected by a legal regime that prosecutes more aggressively those who injure whites than those who injure blacks. See Stephen L. Carter, When Victims Happen to be Black, 97 YALE L.J. 420, $442-47$ (1988); Randall L. Kennedy, McCleskey v. Kemp: Race, Capital Punishment, and the Supreme Court, 101 HARv. L. Rev. 1388, 1390-95 (1988).

26. McCleskey, 481 U.S. at 315-17 (footnotes omitted).

27. The phrase is Justice Brennan's. Id. at 339 (Brennan, J., dissenting). Yet even the dissent attempted to reassure that the $\mathrm{McCleskey}$ challenge was a narrow one, predicated on "the uniquely sophisticated nature of the Baldus study." Id. at 341; see also note 48 infra and accompanying text. 
court employees, and against the lawyers who come to the courts on behalf of litigants.

Task forces have published their results, providing graphs, tables, charts, and testimonial evidence. These materials now form a tall mound, containing serious indictments of many aspects of the legal process across a range of issues. From states as disparate as California, Georgia, Kentucky, Maryland, and Minnesota, one learns that women seeking redress for "domestic" violence are often either blamed, accused of provoking their attacks, treated as if the experiences were trivial, or disbelieved. ${ }^{28}$ When the focus is on race and ethnicity, the reports are similarly distressing; findings include that people of color are less likely to be released on bail than are whites for similar offenses" and "are more likely to be held in custody following conviction and prior to sentencing." 30 Moreover, there is evidence of sentencing disparity "that can be attributed only to race in the rate of convictions and the types of sentences." 31

A significant portion of most of the reports detail problems of bias as experienced by lawyers, court staff, and sometimes by judges themselves. The higher echelons of most judiciaries remain filled with white men. ${ }^{32}$ Courtroom interactions- on and off the record-are often affected by race, ethnicity, and gender bias, and employment opportunities for lawyers and staff are limited by these forms of bias.

28. See Judicial Council of California, Achieving Equal Justice For Women and

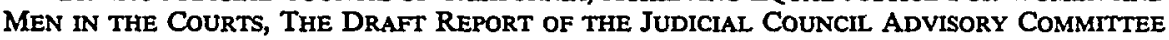
on Gender Bias IN THE CourTs $\S 6$, at $4-5$ (1990) [hereinafter California Draft Gender BIAS REPORT]; GENDER AND JUSTICE IN THE COURTS: A REPORT TO THE SUPREME COURT OF GEORGIA BY THE COMMISSION ON GENDER BIAS IN THE JUDICIAL SYSTEM 20-21 (1991) [hereinafter GEORGIA GENDER BIAS REPORT]; KENTUCKY TASK FORCE ON GENDER FAIRNESS IN THE COURTS 29-31 (1992) [hereinafter KENTUCKY GENDER FAIRNESS REPORT]; REPORT OF THE SPECIAL JoINT COMMITTEe ON GENDER BIAS IN THE COURTS 2-5 (1989) [hereinafter MaRYLaND GENDER Bias REPORT]; MinNesota SUPREME COURT TASK ForCe FOR GENDER FaIRNESS IN THE COURTS, FinAL REPORT, reprinted in 15 WM. MITCHELl L. REV. 825, $875-77$ (1989) [hereinafter MINNESOTA GENDER FAIRNESS REPORT]:

29. Report of tHe New York State Judicial Commission on Minorities, Vol. II, 15051 (1991) (published in five volumes) [hereinafter NEw YORK REPORT ON MINORITIES]; REPORT AND RECOMMENDATIONS OF THE FIORIDA SUPREME COURT RACIAI AND ETHNic BIAS STUdY COMMISSION: “WHERE THE INJURED FLY FOR JUSTICE" 23 (1991) [hereinafter FLORIDA RACIAL/ ETHNic Bias Study, Vol. II].

30. Washington State Minority and Justice Task Force, Final Repor't 11 (1990) [hereinafter WASHINGTON MINORITY AND JUSTICE REPORT].

31. NEW YORK REPORT ON MINORITIES, Vol. I, supra note 29, at 43; see also ALASKa JUdICial Council, Alaska Felony Sentencing Patterns: A Multivariate Statistical ANalYSIS 27-36 (1977) [hereinafter ALASKA FELONY SENTENCING] (Blacks received higher sentences in several categories of cases); ALASKA Judicial CounCIL, INTERIM REPORT OF THE ALASKa JUDICIAL COUNCIL ON Findings OF APPARENT RaCIAL DisparITY IN SENTENCING 54 (1979) [hereinafter ALASKA RACIAL DISPARITY] (race of Blacks and Native Alaskans a factor in denial of probation). But see Memorandum from Judge Robert Boochever to Attendees at the January 27, 1993 meeting on The Effects of Ethnicity, Race and Religion on the Ninth Circuit (Jan. 27, 1993) (statistical evidence of disparity eliminated after the institution of sentencing reforms and training of judges on cultural diversity) (on file with the Stanford Law Review).

32. See, e.g., Florida Racial/Etrinic Bias Study, Vol. II, supra note 29, at 53 (1\% of the judges are women of color); Ninth Circuit Task Force on Gender Bias, Executive Summary, supra note 14, at 2156-57 ("Eighty-eight percent of Ninth Circuit judicial positions are held by men."). 
An overview of the understanding of the justice system that emerges can be found in the general conclusions of such task forces. Although coming from different jurisdictions, the comments are similar:"33 "Women uniquely, disproportionately, and with unacceptable frequency must endure a climate of condescension, indifference, and hostility"; 34 "[W]omen are treated differently from men in the justice system and, because of it, many suffer from unfairness, embarrassment, emotional pain, professional deprivation and economic hardship"; 35 "[T]he perception [is] that minorities are stripped of their human dignity, their individuality and their identity in their encounters with the court system"; "36 "[T] here is evidence that bias does occur with dis-

33. A review of the $\mathbf{3 3}$ reports listed in Appendix $A$ finds a few that do note areas in which there has been progress on gender or race/ethnic issues. See, e.g., GEORGIA GENDER BIAS REPORT, supra note 28, at xi (finding "no widespread and overt gender bias," yet "there is evidence that gender bias does exist within Georgia's judicial system"); KENTUCKY GENDER FAIRNESS REPORT, supra note 28, at 6 (reporting that "experiences in the courts are not as bad as they once were"); Final Report of THE NeW Mexico STAte Bar TASK Force on WOMEN AND THE LegaI Profession 2 (1988) ("although the law has made significant gains," remedial recommendations are still appropriate).

Two reports, both emanating from the local courts of the District of Columbia, have the most positive comments about the current state of gender and racial/ethnic bias in those courts. FINAL REPORT OF THE TASK FORCE ON RACIAL AND ETHNIC BIAS (1992) [hereinafter DC RACIAL/

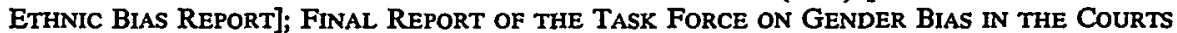
(1992) [hereinafter DC GENDER BIAS REPORT]. The report on racial and ethnic bias noted that these courts are a "unique environment. The majority population of the District of Columbia is African-American, as is the work force in the courts and almost $40 \%$ of the Superior Court judiciary." DC RACIAL/ETHNic BIAS REPORT, supra, at 9. For example, the Task Force concluded that "the evidence presently available did not support a finding of discrimination against racial or ethnic minorities" in the disciplinary system. Id. at 42. Nonetheless concerned about "subtle, not overt" problems, the Task Force called for efforts to enhance inclusiveness. Id. at 19; see also id. at 26 (discussing the failure to "keep up with the growth of the Hispanic community" and the resulting problems of language services and employment).

The task force on gender bias found that the local courts of Washington D.C. were a more hospitable environment than the federal courts in the District because of the presence of many women on the bench and the number of women practitioners. DC GENDER BIAS REPORT, supra, at 93. The task force did find that bias exists, but noted that the evidence did not support a finding of "pervasive" bias. Id. at 98.

34. REPORT OF THE NEW YORK TASK FORCE ON WOMEN IN THE COURTS 5 (1986) [hereinafter NEW YORK GENDER BIAS REPORT].

35. REPORT OF THE CONNECTICUT TASK ForCE ON GENDER, Justice AND THE COURTS 12 (1991) [hereinafter CONNECTICUT GENDER REPORT]; see also REPORT OF THE FLORIDA SUPREME COURT GENDER BIAS STUDY COMMISSION 42 (1990) (finding that "gender bias permeates Florida's legal system today"); THE 1990 REPORT OF THE ILLINOIS TASK FORCE ON GENDER BIAS IN THE CoURTs 5 (1990) (finding that women are "at a disadvantage during [divorce] settlement negotiations"); see also id. at 15 (rape victims are discouraged from prosecuting by "the treatment they receive from the justice system"); see also id. at 28 (while there are not plentiful examples of "overt discrimination . . . more subtle forms of bias persist"); MARYLAND GENDER BIAS REPORT, supra note 28, at iv ("WW]omen's negative experiences cover the range from the aggravating to the lifethreatening. . .."); WASHington STATE TASK ForCE ON GENDER AND JUSTICE IN THE COURTS xvi (1989) ("[G]ender discrimination exists and can negatively impact judicial decision making and affect the outcome of litigation.").

36. New YoRK REPORT ON MinORITIES, Vol. II, supra note 29, at 1; see also Washington MiNORITY AND JUSTICE REPORT, supra note 30, at xxi ("Minorities . . . do not trust the court system to resolve their disputes or administer justice even-handedly"); NEW JERSEY TASK FORCE ON MiNORITY CONCERNS, Final REPORT, 1 N.J. LAWYER 1225, 1230 (Aug. 10, 1992) [hereinafter NEW JERSEY MiNORITY REPORT] ("Minority litigants, minority witnesses, and minority attorneys are subjected to racial and ethnic slights from all levels of court and security personnel-from the bailiff to the bench."); FlORIDA RACIAL/ETHNiC BIAS STUDY, Vol. II, supra note 29, at viii 
turbing frequency at every level of the legal profession and court system."37 In short, the fears of the majority in McCleskey were well-founded: "Unexplained" disparities in treatment correlate with membership in minority groups and "even [with] ... gender." 38

The existence of these task forces and their findings have particular significance for this symposium about the role of legal educators. The $\mathrm{McCles}$ key Court, apparently seeking solace in the limits of social science, used professors' caveats about the import of their findings as the basis for dismissal of the relevance of that work to the justice system. ${ }^{39}$ Whatever knowledge law professors and social scientists might have had about the functioning of the judicial system was disregarded; we were collectively remanded to our classrooms and law reviews.

Task forces do the opposite. They rely on data developed by professors and are willing to accept the difficulties of parsing the many variables that might affect an outcome. Task forces relax the barriers between the worlds of practice and the academy; they invite us (members of the academy) in. Task forces use the very materials-history, social experiences, and quantitative data-rejected by the $\mathrm{McCleskey}$ Court to yield the broad conclusions quoted above. Moreover, these conclusions are officially authored by chief justices and leading jurists and lawyers (and not "only" by academic lawyers and social scientists, and not "only" by members of the group against whom the discrimination runs) and are published in reports literally stamped with a court's seal.

Once issued, these reports have not been met with widespread denial of the existence of the problems documented. Rather, in some jurisdictions, the reports have done a good deal more than simply sit. Proposals for change have been considered, legislation has been passed, and some "progress"-measured in terms of appointments to the bench, integration of court-appointed committees, programs to educate judges and lawyers about their discriminatory patterns, rule changes, and the like-has occurred. Bias is now a topic of judicial conferences, of lawyer meetings, and of private discussions. ${ }^{40}$ Sexual harassment policies have been developed, ${ }^{41}$ canons of

("[E]vidence in Florida suggests that the rights of non-English speaking defendants are systematically being compromised due to the lack of trained, qualified court interpreters.").

37. Final Report of the Michigan Supreme COURT TASK Force on Racial/ETHNic ISSUES IN THE CourTs 2 (1989) Thereinafter MichIGAN RACIAL/ETHNIC REPORT]; see also NEw JERSEY MINORITY REPORT, supra note 36, at 1238 ("Ample evidence supports a broad perception of insensitivity and indifference exhibited sometimes by judges, court employees, members of the bar $\ldots$ and other persons who work in courthouses ..." ).

38. McCleskey, 481 U.S. at 316-17.

39. See, e.g, id. at $293 \mathrm{n} .11$ (quoting "McCleskey's expert" as testifying that models provide information about the "average" and "do not depict the experiences of a single individual"); $i d$. at 308 ("Even Professor Baldus does not contend that his statistics prove that race enters into any capital sentencing decisions or that race was a factor in McCleskey's particular case.") (footnote omitted).

40. For example, see the resolution enacted unanimously by the officers of the Essex County Bar Association of New Jersey, calling for (inter alia) a "permanent task force" on issues of racial/ ethnic discrimination in the courts; a revised bail system "free of bias [that] . . gives minimum weight to economic criteria because such factors generally impact unfairly upon racial minorities"; 
ethics rewritten, ${ }^{42}$ legislation enacted, 43 and training programs on the problems of victims of violence created. ${ }^{44}$ As the five year summary of efforts in New York on women's issues put it: "Now, inescapably, gender bias and the concerns of women are on the agenda." 45 Some celebration is in order, for a measure of success can fairly be claimed. 46

What has not happened is the howl of pain that such findings might have prompted, nor the profound transformation that appears to be demanded. Just as in the classrooms in which the cheerful constitutional story remains largely unchanged, so in the courthouses and judicial systems: no one appears to be shaking in his boots (an apt metaphor given the demographics of the legal profession). Phrases like "there is evidence that bias does occur with disturbing frequency at every level of the legal profession and court system" 47 are uttered, repeated, printed, pronounced, but without much in terrorem effect. Rather, the reports and their conclusions are absorbed, calmed, and translated into another form of polite conversation about the administration of justice, albeit a conversation that affects that administration somewhat.

Like the critical commentaries about legal education, which if fully embraced would require rewriting the basic texts, task force conclusions would also require dramatic upheavals-such as halting the imposition of the death penalty, altering the criteria for sentencing because of findings of differential

\footnotetext{
"cautionary jury instructions relative to . . . cross-racial identification ... "; the "establishment of a non-discriminatory bar examination"; and a requirement that judges read and post statements "opposing racial and ethnic bias in the courts." Memorandum of Robert D. Lipscher to Hon. Theodore Z. Davis, Comments on the Final Report of the Supreme Court Task Force on Minority Concerns 3-4 (Dec. 28, 1992) (on file with the Stanford Law Review); see also Memorandum from Judge Robert Boochever to Attendees at the January 27, 1993 meeting on The Effects of Ethnicity, Race and Religion on the Ninth Circuit, supra note 31, at 2-4 (Alaska programs on cultural awareness and sentencing reform reduced statistical evidence of discrimination based on race).

41. See, e.g., U.S. DISTRICT COURT \& U.S. BANkRUPTCY COURT, WESTERN DisTRICT OF Washington, Sexual HaRassment Policy 1 (Feb., 1993) (applicable to "a member of the District or Bankruptcy Clerk's Offices, Probation Office, Pretrial Services Office, or judicial staff' as well as to "any non-staff person") (on file with the Stanford Law Review).

42. See, e.g., Mich. Bar Approves Antibias Rules for Codes of Conduct, Bar Leader, Nov.Dec. 1990, at 4-5 (state bar approves new rules that provide that lawyers and judges not "engage in invidious discrimination on the basis of gender, race, religion, disability, age, sexual orientation, or ethnic origin, and shall prohibit staff and agents subject to the lawyer's direction and control from doing so."); AMERICAN BAR Association, MOdel CODE OF Judicial Conduct Canon 2(C) (1990) ("A judge shall not hold membership in any organization that practices invidious discrimination on the basis of race, sex, religion or national origin.").

43. See, e.g., Fla. STAT. ANN. $\S 43.29$ (West Supp. 1993) (requiring that each judicial nominations commission shall be composed of three members, "at least one of whom must be a member of a racial or ethnic minority group or a woman"); N.Y. CRIM. PROC., \$ 170.55(4) (McKinney Supp. 1993) (permitting adjournments in contemplation of dismissal conditioned on a defendant attending educational programs on family violence).

44. See Five Year Report of the New York Judicial Committee on Women in the COURTS 27-31 (1991) [hereinafter NEW YORK FIVE YEAR REPORT].

45. Id. at 44.

46. A more optimistic view is expressed by Norma Wikler's metaphor, "water on stone"--that task forces will wear away discrimination, as water wears away stones. Wikler, supra note 16.

47. See Michigan Racial/Ethnic Report, supra note 37, at 2. Compare the title of an ongoing task force in Canada-Commission on Systematic Racism in the Ontario Criminal Justice Stystem.
} 
treatment, and finding different means of protecting women from violence. But in both classroom and courtroom, the routine supported by assertions of constitutional order endures. McCleskey remains the template. Even as the dissent chastised the majority for its unwillingness to consider Warren McCleskey's claim of racial discrimination, the dissent reassured the majority that its "projection of apocalyptic consequences for criminal sentencing [was] . . . greatly exaggerated."48 The prediction has proved accurate: Although task forces find pervasive discriminatory behavior (predicated on race, ethnicity, and "even gender") that affects the judicial process in a myriad of illicit ways, "apocalyptic consequences" have not followed.49 The powerful structures of the law (and of culture in the United States in general) can even authorize inquiry, ask forbidden questions, obtain information, and still remain impenetrable to profound change. The fundamental accusation-oppression intrinsic in the delivery of justice-remains beyond comprehension. ${ }^{50}$

Thus, a first conclusion is that a decade of academic and court-based documentation of deep-seated and endemic unfairness has not undermined the resiliency of legal culture as expressed by those who lead the bench, bar, and academy, who are by definition those of us with privilege. In classrooms, in courtrooms, and in the intersections such as task forces, in which lawyers, judges, and academics join together, the responses have been consistent. Even as we tell of the horrors of the many forms of discrimination, we somehow continue to tell of the joys of legalism and of the hope that we can "fix" it-that the conditions we find are but temporary aberrations rather than aspects deeply anchored in and intrinsic to our history. ${ }^{51}$ Task force

48. 481 U.S. at 342 (Brennan, J., dissenting).

49. Indeed, there is evidence to suggest that certain forms of race- and gender-based discrimination have been exacerbated over the last decade. See Vicki Schultz \& Stephen Petterson, Race, Gender, Work, and Choice: An Empirical Study of the Lack of Interest Defense in Title VII Cases Challenging Job Segregation, 59 U. CHI. L. REv. 1073 (1992) (examining judicial responses to defenses to job segregation with the claim that either "women" or "minorities" "prefer" certain kinds of work; finding that this "lack of interest" defense, identified in sex discrimination cases, is now being accepted as a justification for racial segregation; and concluding that these decisions evidence court-based gender and race bias.)

50. Recall the majority's words: "McCleskey challenges decisions at the heart of the State's criminal justice system." McCleskey, 481 U.S. at 297.

51. Both the absence of horror and the aspirations about the capacity to fix some of the problems documented by task forces rely in part on the fact that many task forces focus on courtroom interaction and the legal profession. Finding the absence of people of color and white women in the higher echelons of court systems comes neither as a great surprise (the idea of an exclusionary workplace is familiar) nor as a source of outrage (debates on affirmative action have muffled such responses). Further, given the miseries of so many aspects of human life, while exclusion from the judiciary and the legal professional elite is undesirable, it is not awful. Similarly, the completeness of the exclusions (such that, as of 1991, 60 of the 94 federal trial courts had no life-tenured judges who were women, and of 64 sitting bankruptcy judges in 1992 within the Ninth Circuit, none were persons of color) avoids aspects of the affirmative action debate. Whatever one's views about quotas, many are willing to see zero as an unacceptably low number and are willing to look for (if not find) "qualified candidates."

The focus on the demographics of the courts and the working environment is not only more palatable, it is in turn fueled by the resource constraints that haunt task forces. As is familiar both to social scientists and lawyers, counting individuals is far easier than identifying and specifying the 
reports have not borrowed Robert Cover's title, "Justice Accused,"52 but instead label their work as "gender equity" and "fairness in the courts." 53

A second conclusion stems from my noncasual use of the word "we" in the paragraph above, a word that is often used deliberately by law professors and by judges in classrooms and on task forces. The "we" is not only proof of the ubiquity of the cheerful story; it is also proof of contemporary affirmation of the aspirations of that story. Both the legal academy and the task forces are constantly in the process of reaffirming-pledging allegiance-to this constitutional faith. But not all who invoke the "we" (either in the academy or in the courts) share world views; further, within some of the current critical academic commentary, the reliance on a "we" is a central topic of concern. By examining some of the different political views (associated in contemporary legal education with differing schools of scholarship) that can underlie the invocation of a "we," I hope to illuminate the interaction between academic theory and contemporary legal reform efforts and to join others in developing alternative understandings of this legal regime.

A first and powerful set of arguments that rely on and substantiate the use of the word "we" comes from a school of thought known as civic republicanism. Indeed, court-based task forces on discrimination can be understood as civic republicanism (in the Frank Michelman and Cass Sunstein sense, ${ }^{54}$ without the Kathleen Sullivan criticism ${ }^{55}$ ) played out in practice. "We," with some power of governance, join together in dialogue to recommit to the values of equality and justice by sharing in the common enterprise of reconsidering the means by which justice is delivered and by declaring a readiness to change, when necessary.

interaction among the many variables that result in courtroom decisions. As the New York Five Year Report put it: "Many of the most damaging problems the Task Force found simply defy objective measurement. Among these are the attitudes of judges, the atmosphere in courtrooms, and perceptions of credibility." NEW YORK FIVE YEAR REPORT, supra note 44, at 43. (1975).

52. Robert M. Cover, Justice Accused: ANTiSlavery and the Judicial Process

53. Such a choice is not surprising, given the "insider" quality of the authors of the task forces. Such involvement-first to gain the imprimatur of the court and then to use that authority to effectuate change-diminishes the possibility of aggressive accusations, for "we" must accuse ourselves. See Joan Entmacher, Dissonant Discourses: Legal Ideology and Feminist Theory in the Work of Task Forces on Gender Bias in the Courts (1990) (unpublished manuscript, on file with the Stanford Law Review) (effects of obtaining legitimation include dampening of critical commentary).

54. See Frank Michelman, Law's Republic, 97 YaLE L.J. 1493, 1502-03, 1526 (1988) (calling for a revival of earlier United States' political thought about participation, dialogue, and plurality so as to inform contemporary constitutional analysis and to enable it to become (borrowing Robert Cover's phrase) "jurisgenerative" and to flourish in the "modern context of equality of respect, liberation from ascriptive social roles, and indissoluble plurality of perspectives"); Cass R. Sunstein, $B e-$ yond the Republican Revival, 97 YALE L.J. 1539, 1541 (1988) (detailing republicanism's commitment to "civic virtue," "equality of political actors," "universalism," and "citizenship" (i.e., participatory rights) and showing how those values, as reformulated, affect constitutional understandings of the regulation of electoral politics, the allocation of power between state and federal government, and the treatment of discriminated-against minorities).

55. Kathleen M. Sullivan, Rainbow Republicanism, 97 YALE L.J. 1713, 1718, 1722 (1988) (arguing that the Michelman/Sunstein views of the ability to incorporate involuntary groups in the new models of republicanism are inconsistent with their assumptions about the capacity to arrive, by dialogue, at agreement and at shared understandings of "a single common good."). 
Further, as is illustrated in Frank Michelman's essay, this "we" wants to believe that "we" are inclusive and egalitarian; "we" have a hard time acknowledging how deeply flawed and resistant to change the political structure is. Michelman defines "American constitutionalism" as based on "two premises regarding political freedom: first, that the American people are politically free insomuch as they are governed by themselves collectively, and, second, that the American people are politically free insomuch as they are governed by laws and not men [sic]."56 But he adds a qualification to that definition-a "sic"- to signal the reader that the word "men" is an error in the original phrase, not his.

However, as task forces on bias as well as recent televised hearings of senatorial committees remind us, the "sic" is no error, no vestige of bygone days, but an accurate contemporary description. ${ }^{57}$ In the "sic" is revealed both the commitment to better justice and the reluctance to see gendered justice. In the task forces, as in Michelman's essay and in many law school classes, gender neutral language is substituted-to express the desire to include. Unfortunately, that language can also have the pernicious effect of implying that the task of inclusion has been accomplished. Further yet, it assumes that inclusion, rather than transformation-a change in the basic narrative-is the desired end-point.

A second source for the use of "we" comes not from scholars attempting to explore how, despite and sometimes because of difference, conversation can proceed to produce a common good, but from law and economics scholars who often assume a universally shared set of values that requires no further specificity. Law and economics models play this out, not only through their reductionist assumptions but also by the central term of the discourse-“"rationality." It is not always clear whether such universalizing stems from commitment to political theory or from ignorance. Some of those who claim the "we" do not appear to know that they lack the authority to use it, nor seem to have considered that they should be circumspect before assuming the ubiquity of their own experiences. ${ }^{58}$

But of course, law and economics scholars are by no means outliers in claiming generalizability; such is the stuff of most forms of theory. The problem is central to contemporary feminist theory, which in turn has special relevance to the work of gender bias task forces. Within feminist theory, deployment of the word "we" often raises the charge of "essentialism." The concern is about the use of "woman" as a universal category. The critique addresses two sets of claims. First, the category "woman" has been used by men to essentialize women's nature and then to oppress. Second, the cate-

56. Michelman, supra note 54, at 1499-1500 (footnotes omitted).

57. Given a president and vice president who are male, a Congress that is overwhelmingly male, and that 72 women hold statewide elected executive positions, governance by "men" seems a more than fair description. Center for the American Woman and Politics, Statewide Elective Executive Women 1993 (fact sheet) (April 1993) (on file with the Stanford Law Review); see also Women on the Ballot: Female Ranks in Elected Jobs get a Big Boost, N.Y. TIMES, Nov. 8, 1992, at 28 (citing 1992 figures).

58. My colleague Catharine Wells has nicely termed this "psychological imperialism." 
gory "woman" has been used: by white women, claiming to speak for women of other colors; and/or by straight women, claiming to speak for women who are lesbian or bisexual; and/or by middle class women, claiming to speak for lower class women; and/or by younger women, claiming to speak for aging women. The criticism is that first men, and then women of relative power (in terms of access to the means of publication) within the women's movement, have used their platforms to explain, and therefore negate, erase, or appropriate, the experiences of those unlike themselves. ${ }^{59}$

Unilike modes of legal scholarship that express no interest in the problem of essentialism, contemporary feminism-both within and without the legal academy ${ }^{60}$-is much absorbed with this problem and how to respond. Within feminism, the "we-sayers" have replied sometimes with a confession of error, sometimes with a retreat to particularity, and sometimes with a rejection, based on the view that "women" remains the relevant category. Yet, here I want to point to a discontinuity between classroom and courtroom critiques. Feminism's concern about the propriety of the use of the word "we" (here standing for all women) is not much in evidence in the published gender bias task force reports, ${ }^{61}$ which are themselves the product of feminism. The generic "woman" is often invoked in these reports. Hence the questions: Why is the general category of "woman" such a constant refrain in gender bias task forces? How might that fact inform feminist theory? And how might it inform the understanding of the persistence of constitutional faith and of the possibility of telling other stories of the past and present?

Responding requires a return to the task forces on gender bias and racial and ethnic bias with the "we" question in mind. The first gender bias task force project was launched in 1982, before much of the writing on the problem of essentialism was published in the legal literature. ${ }^{62}$ In 1986, the Judicial Education Program of the NOW Legal Defense and Education Fund and the Foundation for Women Judges provided a manual to guide the work of the many jurisdictions addressing the issue. That manual counsels against exploring race and gender together, for fear of "overload and confusion" of focus. ${ }^{63}$ The manual advises "awareness" of the intersections of other forms

59. See AUdre LORDE, SISTER OUTSIDER 110-23 (1984); AdrIENNE RICH, Compulsory Heterosexuality and Lesbian Existence, in Blood, BREAD, AND POETRY: Selected Prose 1979-1985, at 23 (1986); Kimberle Crenshaw, Demarginalizing the Intersection of Race and Sex: A Black Feminist Critique of Antidiscrimination Doctrine, Feminist Theory and Antiracist Politics, 1989 U. CHI. LEGAL F. 139; Angela P. Harris, Race and Essentialism in Feminist Legal Theory, 42 STAN. L. ReV. 581 (1990).

60. See, e.g., Elizabeth V. Spelman, Inessential Woman: Problems of Exclusion in Feminist Thought (1988); Linda Gordon, On "Difference," 10 Genders 91 (1991).

61. See notes 65-68 infra and accompanying text.

62. See, e.g., Crenshaw, supra note 59 (1989); Harris, supra note 59 (1990); see also Regina Austin, Sapphire Bound!, 1989 WISC. L. REv. 539; Mari J. Matsuda, When the First Quail Calls: Multiple Consciousness as Jurisprudential Method, 11 WOMEN's RTS. L. REP. 7 (1989).

63. LyNn Hecht Schafran \& NORMa Juliet WikLer, Operating a TASK Force on Gender Bias in the Courts: A MANUAL for Action 6 (1986) (a section of the manual is entitled "The Task Force Should Deal with Gender Bias Only" and the authors explain: "[A]ttempting simultaneously to investigate all forms of racism and other kinds of bias in addition to 
of bias with gender and suggests that other task forces be directed to address the other "isms." 64

Unfortunately, the hoped-for awareness of the intersections of gender, ethnicity, race, and sexual orientation has not much been translated into data and commentary in the twenty plus reports now published on gender and the courts. Women of color are, with a few exceptions, not discussed. ${ }^{65}$ Sexual orientation is also rarely addressed. ${ }^{66}$ Task forces on race and ethnic bias have also not devoted sustained attention to women of color. ${ }^{67}$ Excep-

sexism at an appropriate level of detail would be impossible within the constraints imposed on a Task Force."); cf. Presentation of Judge Gladys Kessler, Second National Conference on Gender Bias in the Courts 8 (Mar. 18, 1993) (unpublished speech, on file with the Stanford Law Review) (urging task forces on race and gender to be convened at the same time because, while each group should have "separate leadership and membership," interaction between them is important). The Foundation for Women Judges has since been renamed the Women Judges' Fund for Justice.

64. SCHAFRAN \& WIKLER, supra note 63, at 6 . The six jurisdictions that have thus far published reports on race and gender may well have taken this advice. Three (New Jersey, New York, and Washington) published gender reports first, and then published race/ethnic reports thereafter. Three (the District of Columbia, Florida, and Michigan) have published the results of two concurrently-sitting task forces, one on gender and one on race/ethnicity.

65 . Of the 24 reports on gender considered here, only a few discuss, sometimes briefly, the distinctive status of being both a woman and of color. See, e.g., CalifornIA DRAFT GENDER BIAS REPORT, supra note 28, at $\$ 10$ (describing the concomitant effects of gender and racial and ethnic bias); CONNECTICUT GENDER REPORT, supra note 35, at 83 (finding that "black women's average sentence length was 10.5 months longer than white women's"); DC GENDER BIAS REPORT, supra note 33, at 62 (noting lack of African-American women in the upper echelons of the court's workforce); KENTUCKY GENDER FAIRNEsS REPORT, supra note 28, at 8, 22, 35 (reporting that minority women law professors encounter "greater barriers" than white women and men of all colors; African-American women were less likely to receive alimony than white women in divorce litigation and more likely, in criminal litigation, to be charged if apprehended for shoplifting); FiNAL REPORT OF THE MICHIGAN SUPREME COURT TASK FORCE ON GENDER ISSUES IN THE COURTS 10-12, 21 (1989) (analyzing data based on "race and gender" profiles, discussing problem of "category blending," and breaking out responses based on majority and minority males and females); NEW YORK GENDER REPORT, supra note 34, at 195-97 (race affecting credibility); id. at 253 (mentioning minority women as court employees); NINTH CIRCUIT GENDER BIAS TASK ForCE, PRELIMINARY REPORT 104-12 (discussion draft, July 1992) (the problems of immigrant women) [hereinafter Nintm Circuit Task Force Preliminary ReporT]; id. at 128-38 (the obstacles to law enforcement efforts to protect women members of Indian tribes from crimes of violence). The District of Columbia's Task Force on Gender Bias considered issues of child abuse and neglect, and reported that it was the first to do so; such a choice might refiect concern about the intersections of race, ethnicity, and gender. DC GENDER BIAS REPORT, supra note 33, at 165-74.

66. See, e.g., CALIFORNIA DRAFT GENDER BIAS REPoRT, supra note 28, $\$ 4$ at 33, 62 (proposing that judges be prohibited from discriminating on grounds of sexual orientation, race, gender, or ethnicity); GEORGIA GENDER BIAS REPORT, supra note 28, at 185 (noting press commentary that judges discriminate on the basis of "sexual lifestyle" when making child custody decisions); REPORT OF THE GENDER BIAS STUdy OF THE SUPREME Judicial COURT: COMMONWEALTH OF MASSACHUSETTS $65 \mathrm{n} .56$ (1989) (nearly one fifth of lawyers responding reported judicial discrimination in custody decisions against "lesbian or gay parents").

67. Florida's report on racial and ethnic bias is the only one that devotes a chapter to issues of women of color; the specific focus is on "minority women employees and attorneys." FLORIDA RACIAL/ETHNIC BIAS STUDY, Vol. II, supra note 29, at 49-60. Other reports occasionally mention women of color. See, e.g, DC RACIAL/ETHNIC BIAS REPORT, supra note 33, at 18 (discussing the differences in hiring patterns of Black and White females); MICHIGAN RACIAL/ETHNIC REPORT, supra note 37, at 40, 42, 62, 64 (reporting data delineating majority males and females from minority males and females); NEW YORK REPORT ON MINORITIES, Vol. I., supra note 29, at 22 (noting that "[r]acial bias against litigants is sometimes compounded by gender bias"); WASHINGTON MINORITY AND JUSTICE REPORT, supra note 30, at 65-66, 68-69, 76 (noting "how the combined effects of race, ethnicity and gender are related to law practices and incomes" and to legal education); id. at 110-15 
tions exist, as a few of the reports make mention of the intersections of gender, race, and ethnicity. ${ }^{68}$ It is not yet clear whether the growing concerns of feminist legal literature about essentialism and the ongoing discussions within women's organizations about this issue will result in changes in the task forces' agendas. ${ }^{69}$

Explanations of why women of color have not, until recently, been a focus of task forces mirror those about the development of awareness of diversity among women within the legal academy. Those with the power to speak, speak first from their own experience, but do not always know (or care) that they are assuming the generalizability of that experience. Most of the "first" women in law were white women, ${ }^{70}$ many of whom deserve credit for putting "women's issues" on the agenda. The failure to differentiate among women may have stemmed from unself-conscious assumptions of sameness, from theoretical commitment to sameness, and/or from strategically motivated views about how to obtain some gains. ${ }^{71}$ This sameness thread in feminist theory and practice is related to the constitutional story of inclusion (the impulse to edit the phrase about constitutionalism being a government of laws, not men, to add "women"). The deployment of the "we," however, can be heard as welcoming or oppressing, or both.

Task forces emerge out of political and social settings in which their official sources can rarely be women of color. Not only were white women the first entrants to the legal academy as law students and professors, recent studies continue to document discrimination against women of color ${ }^{72}$ and have not yet asked the question in the context of class and sexual orienta-

(data on representation of people of color in court employment); NEW JERSEY MINORITY REPORT, supra note 36, at 1231 (female "minority prisoners" affected by "multiple factors,"); id. at 1245 (discussion by president of Black Women Lawyers' Association); id. at 1266 (workforce data by color and gender).

68. E.g., Florida Racial/Ethnic Bias Study, Vol. II, supra note 29; NinTH Circuit TASK Force PReliminary RePort, supra note 65; NEW YoRK GENDER BIAS RePORT, supra note 34, at 195-97 (titling one subsection "Race and Economic Status as Affecting Credibility"). At least one ongoing task force on gender and racial bias, that of the federal courts for the District of Columbia, has divided into one group focusing on race and one on gender, and the gender group has a subcommittee devoted to Class, Race, and Gender issues.

69. Another source of attention to the issue of women of color comes from members of the National Consortium of Task Forces and Commissions on Racial and Ethnic Bias in the Courts. They conducted a panel discussion on the topic at the Second National Conference on Gender Bias in the Courts, held in March of 1993 and co-sponsored by the NCSC, the National Association of Women Judges, and the Women's Fund for Justice.

70. See Karen Berger Morello, The INVisible Bar 142-72 (1986) (chronicling black women's admission to law schools and the bar); id. at 148 ("[By] the 1940 s there were only fiftyseven black women lawyers in the entire United States."); Barbara Allen Babcock, Clara Shortridge Foltz: Constitution-Maker, 66 IND. L.J. 849 (1991); Barbara Allen Babcock, Clara Shortridge Foltz: "First Woman," 30 ARIZ. L. REv. 673 (1988).

71. As Linda Gordon understands this problem of feminism, this approach may have "held back possibilities for political unities among women: by postulating gender difference so intensely, white feminists had tended to render minority cultures less visible and minority feminists had to respond by emphatically exploding false postulations of sisterhood." Gordon, supra note 60, at 100 .

72. Deborah J. Merritt \& Barbara F. Reskin, The Double Minority: Empirical Evidence of a Double Standard in Law School Hiring of Minority Women, 65 S. CAL. L. REv. 2299, 2301 (1992) (from 1986-1991, minority women joined law faculties at lower ranks, were assigned lower status teaching positions, and were hired at less prestigious schools than minority men). 
tion. ${ }^{73}$ The relatively few women of color in the legal profession are often both low in the hierarchy ${ }^{74}$ and asked constantly to lend their efforts to hundreds of projects that have suddenly become self-conscious about the whiteness and maleness of their committees. The composition of the judiciaries that in turn empower task forces reflect this pattern. Six women described as "minorities" currently sit on the highest courts of their jurisdictions.75 Few women of color are senior members of law firms, United States Attorneys, chiefs of public defender offices, leaders of public interest law projects, ${ }^{76}$ or holders of chairs on law school faculties. The fact that women of color are not sufficiently represented in the ranks of the powerful does not, of course, document their absence from the subject matter of the work-or the absence of effects of gender and race on justice. But their absence from positions of power explains to some extent the evolution of an agenda that has not attended to the discrete issues of women of color and has assumed the racelessness of white women.

But why do white women with some power not insist on the inclusion of women of color as a central part of the project? (Note here that I frame the question not in terms of all members of task forces, which in fact include and

73. In 1990, the American Association of Law Schools changed its by-laws to require schools to "pursue a policy of providing [their] students and graduates with equal opportunity to obtain employment, without discrimination ... on the ground of race, color, religion, national origin, sex, age, handicap or disability, or sexual orientation." Association OF AMERICAN LAW SCHOOLS, 1993 HANDBOOK 31-32 (1993) (art. 6, § 4(b) of By-laws). Implementation efforts have been controversial, in part because one of the most visible discriminators has been the United States military. See Christopher R. McDowell, The AALS Sexual Orientation Policy: The Argument Against Barring Military Recruiters from Law School Campuses, 95 W. VA. L. REv. 163 (1992); Gene P. Schultz, The Inclusion of Sexual Orientation in Nondiscrimination Policies: A Survey of American Law Schools, 2 L. \& SEXuALTTY 131 (1992).

The California Bar has begun to learn about the effects of sexual orientation on its membership. See Susan H. Russell \& Cynthia L. Williamson, Demographic SuRvey of the STate Bar OF CALIForNIA 2 (1991) (membership survey of bar that included questions about whether respondents considered themselves members of the "gay, lesbian, or bisexual community," to which three percent of the respondents answered in the affirmative).

74. FIORIDA RACIAL/ETHNiC Bias StUdY, supra note 29, at 53 (1\% of all judges in Florida are women of color).

75. They are: Joyce L. Kennard (California Supreme Court); Judith W. Rogers (Court of Appeals for the District of Columbia); Julia Cooper Mack (Court of Appeals for the District of Columbia); Annice Wagner (Court of Appeals for the District of Columbia); Rosemary Barkett (Florida Supreme Court); Leah J. Sears-Collins (Georgia Supreme Court); and Dorothy Comstock Riley (Michigan Supreme Court).

Of the fifty states and the District of Columbia, three have female chief justices, of whom two (Judith Rogers of the District of Columbia and Rosemary Barkett of Florida) are women of color. This information is derived from THE LAwYeR's AlMANAC: A COMPLETE ReFerence to VITAL Facts AND Figures ABOUT THe Legal Profession 995-99 (1993), and the ABA, The Directories of the Minority Judges in the United States of America, § I at 35, 45, 140; § II at 5, § III at 30, 40 (1992). Judge Wagner is the chair of the District of Columbia's Task Force on Gender Bias in the Courts and, to my knowledge, is the only woman of color who sits both on the highest court of her jurisdiction and on a race or gender bias task force.

76. See Catherine S. Manegold, Memories Drive NAACP Fund's New Leader, N.Y. TIMES, Jan. 29, 1993, at B10 (Elaine Jones is the "first woman" to head the NAACP Legal Defense and Education Fund and, in the late 1960s, was the first Black woman ever to graduate from the University of Virginia Law School). 
are often chaired by men, ${ }^{77}$ but rather ask it of white women, whom I perceive as specially-obligated and situated to understand the importance of distinctions among women.) Just as in the academic literature, so as in life: The response is sometimes a confession of error, sometimes a retreat to particularity, sometimes an explanation that resources do not permit more, and sometimes a rejection, based on the view that "women" remains the relevant category.

But there is something else that is true in life, and may well be true, but unsaid, in the literature. If and when white women attempt to lend their hands to the work of exploring the intersections of race and gender, they (or more accurately, "I" here: white and a member of a task force and not sure whether I speak for others) risk wanting to "yell" at all men, including those who are members of minority communities. But I fear that any criticisms will be used oppressively by the majority male community. To be blunt, given the controversy about Anita Hill's decision to complain about the behavior of a black man, ${ }^{78}$ white women are (and should be) reticent to give voice to such complaints. And should also be reticent about not giving voice to such complaints. "Skipping" race, blurring race, or leaving race to another task force are ways to avoid the discomfort, albeit not the issues. The impulse is to escape into a "we."

Here is the core, as I experience the "essentialism" question in my life as scholar, law professor, and task force member. I, a white woman, (appropriately) fear that my actions and voice will volitionally or inadvertently continue to oppress those who are not white. I, a white woman, also believe in the relevance of my womanhood and of the experiences that make me feel kinship across racial, ethnic and other lines more readily with women than with men. I, a white woman, believe I have an obligation not to speak for all women at all times and moreover have an obligation to identify distinctions among women. I, a white woman, also want to insist on the continued relevance of the category "woman" for certain times and places, and in particular, for the structure of the law. ${ }^{79} \mathrm{I}$, a white woman, keenly aware of the limits of my own experience, feel an obligation to seek the participation of nonwhite women in the academic and worldly work I do, and I, a white woman, feel self-conscious about the burdens my needs for conversation may impose on women of color.

I, a white woman, also see that frame-“I, a white woman"-as too nar-

77. As the manual on gender bias task forces notes, "[a]nother requisite for a Task Force is a number of male judges, lawyers or judicial educators concerned about the problem and willing to participate. Their involvement enhances the credibility of the Task Force and bolsters interest and support in the judicial/legal community." SCHAFRAN \& WIKLER, supra note 63, at 6 .

78. See, e.g., Margaret A. Burnham, The Supreme Court Appointment Process and the Politics of Race and Sex, in RACE-ING Justice, EN-GENDERING Power: EsSays on ANITA Hill, ClaRenCE Thomas, AND the Construction of Social Reality 290, 308-15 (Toni Morrison ed., 1992).

79. Thus I object to the Supreme Court's refusal to recognize pregnant women as a class and to understand the relationship between discrimination against pregnant women or all women. See Bray v. Alexandria Women's Health Clinic, 113 S. Ct. 753, 759-62 (1993). 
row, too fixed, too acontextual. I see many aspects of personhood, both within myself and others, and believe there are dynamic relationships among class, race, gender, religion, sexual orientation, and age such that the saliency of these characteristics is not stable but varies in context. ${ }^{80} \mathrm{I}$, a white law professor, have many times heard and told of the United States' legal structure as centrally about the domination of whites over blacks. I, a woman raised on the East Coast, see the impulse to frame the story of race as about black and white relations and specifically as about how African-Americans relate to whites. I, living in Los Angeles, see the inadequacies of that paradigm in a setting of multi-racial/ethnic conversations, in which whites are a numerical minority. ${ }^{81} \mathrm{I}$, a task force member and law review writer, rebel at phrases such as "women and minorities" and know the need for other language-and know that it is not repeating the "laundry list" of "the groups" that forms a response sufficient to this problem. I say all of this in the voice of extreme particularity-I, I, I-but I suspect that my feelings may be shared by others. 82

And so I return to the two pulls-the fundamental critique of law and the impulse to believe (let alone to tell) the cheerful story. The low visibility of women of color in the task force reports on both gender and race is yet another example of the accuracy of the critique. The more one looks, the thicker become the data of exclusion, oppression, and silence, all the while under the invocation of the universal "we." But in theory, the cheerful story tells me that I too will have occasion to speak, to participate in the dialogue, ${ }^{83}$ to shape the polity's norms, and thus it gives me a wedge, a claim about the authority to speak and about the possibility of change. ${ }^{84}$ With that story, I can focus on the very existence of feminism within law schools, on the fact of task forces at all, and on the conversations that have begun to move us away from the "shell game of identity politics." 85 It is thus not surprising that, for me and many others with the power to tell it, it is hard to leave the cheerful constitutional story behind.

80. In Dependent Sovereigns: Indian Tribes, States, and the Federal Courts, supra note 7, at 702-27, I developed this point in the context of analysis of the relationships among Indian tribes (which are themselves constructs of United States' law), the federal government, and the states. Determining the meaning of "membership" in the Santa Clara Pueblo depended on who was asking that question, and for what purpose. See also Santa Clara Pueblo v. Martinez, 436 U.S. 49 (1978).

81. Whether the meaning and deployment of the term "minority" will be stable over time is questionable; its current usage connotes not only small numbers but also relatively little power.

82. For other white women's explorations of related themes, see Gordon, supra note 60; Deborah L. Rhode, Enough Said, 4 YALE J.L. \& FemINISM 35 (1991) (describing the discomfort as a white feminist in discussion about difference); Christine Stansell, White Feminists and Black Realities: The Politics of Authenticity, in RACE-ING JUSTICE, EN-GENDERING POWER, supra note 78, at 251.

83. Here I am back at civic republicanism. See notes 54-56 supra and accompanying text.

84. I thus share critical race theory's critique of critical legal studies. See Kimberle Williams Crenshaw, Race, Reform, and Retrenchment: Transformation and Legitimation in Antidiscrimination Law, 101 HARv. L. REV. 1331 (1988); Patricia J. Williams, Alchemical Notes: Reconstructing Ideals from Deconstructed Rights, 22 HARV. C.R.-C.L. L. REV. 401 (1987).

85. This nice phrase is Christine Stansell's. Stansell, supra note 82, at 266. 
APPENDIX A: REPORTS ON GENDER, RACIAL, AND ETHNIC BIAS IN THE COURTS

I. RACE AND Ethinic Bias TASK Force Reports

Final Report of the Task Force on Racial and Ethnic Bias and TASK Force ON GENDER BIAS IN THE COURTS (District of Columbia, 1992)

REPORT AND RECOMMENDATIONS OF THE FLORIDA SUPREME COURT RACIAL AND ETHNIC BIAS STUDY COMMISSION, "WhERE THE INJURED FLY FOR JUSTICE," Vol. One (Florida, 1990)

REPORT AND RECOMMENDATIONS OF THE FLORIDA SUPREME COURT RACIAL AND ETHNIC BIAS STUdY COMMISSION, "WhERE THE INJURED FLY FOR JUSTICE," Vol. Two (Florida, 1990)

FinAl REPORT OF THE Michigan SUPREME COURT TASK ForCE ON RACIAL/ETHNIC IsSUES IN THE COURT (Michigan, 1989)

New Jersey Supreme Court Task Force on Minority Concerns, INTERIM REPORT (New Jersey, 1989)

New Jersey Supreme Court Task Force on Minority Concerns, FINAL REPORT (New Jersey, 1992)

REPORT OF THE New York State Judicial Commission ON MinORITIES (NEW YORK, 1991):

VOlUME ONE: EXECUTIVE SUMMARY

Volume Two: The Public and The Courts

VOLUME THREE: LEgal EDUCATION

Volume Four: Legal Profession, Nonjudicial Officers, EMPLOYEES AND MINORITY CONTRACTORS

VOLUME FIVE: APPENDIX-STAFF REPORTS AND WORKING PAPERS

Minority and Justice Task Force, State of Washington: Final REPORT (Washington, 1990)

II. GENDER Bias TASK Force REPORTS

A. Federal Reports

Ninth Circuit Gender Bias Task Force, Preliminary Report: DisCUSSION DRAFT AND EXECUTIVE SUMMARY (1992)

B. State Reports

Achieving EQual Justice for Women and Men IN THE Courts, The DRAFT REPORT OF THE JUDICIAL COUNCIL ADVISORY COMMITTEE ON GENDER BIAS IN THE COURTS (California, 1990)

* This Appendix provides a list, by jurisdiction, of the reports reviewed for this essay. The National Center for the State Courts provides updated information on the work of gender, race, and ethnic bias task forces. 
Gender \& Justice in the Colorado Courts, Colorado Supreme Court TASK Force ON GENDER Bias IN THE CourTS (Colorado, 1990)

REPORT OF THE CONNECTICUT TASK ForCE, GENDER, JUSTICE AND THE COURTS (Connecticut, 1991)

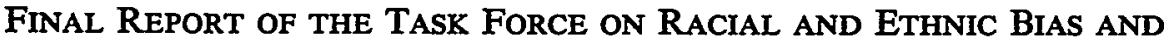
TASK ForCe ON GENDER BIAS IN THE COURTS (District of Columbia, 1992)

Report of the Florida Supreme Court Gender Bias Study ComMISSION (Florida, 1990)

GeNDER AND JUSTICE IN THE COURTS: A REPORT to THE SUPREME COURT OF GEORgIA BY THE COMMISSION ON GENDER BIAS IN THE JUDICIAL SYSTEM (Georgia, 1991)

Achieving Gender fairness: Designing a Plan to Address GenDER Bias In HaWAII's Legal System, REPORT OF THE AD Hoc COMMITTEE ON GENDER BiAs (Hawaii, 1989)

THE 1990 REPORT OF THE ILLINOIS TASK FORCE ON GENDER BIAS IN THE CoURTS (Illinois, 1990)

Kentucky TASK Force on Gender FaIRness in the Courts, EQUAL JUSTICE FOR WOMEN AND MEN (Kentucky, 1992)

LOUISIANA TASK FORCE ON WOMEN IN THE COURTS: FINAL REPORT (Louisiana, 1992)

Maryland Speical Joint Committee, Gender Bias in the Courts (Maryland, 1989)

REPort ON THE GeNDER Bias Study OF THE SuPreme Judicial Court (Massachusetts, 1989)

Final RePort of the Michigan Supreme Court Task Force on GENDER ISSUES IN THE COURTS (Michigan, 1989).

Report of the Minnesota Surpreme Court TASK Force for GenDER FAIRNESS IN THE COURTS, FINAL REPORT (Minnesota, 1989)

JUSTICE FOR WOMEN: FirST REPORT OF THE NEVADA SUPREME COURT TASK ForCE ON GENDER BIAS IN THE COURTS (Nevada, 1988)

The First Year Report of the New Jersey Supreme Court Task FORCE ON WOMEN IN THE COURTS (New Jersey, 1984)

The Second Report of the New Jersey Supreme Court Task Force ON WOMEN IN THE COURTS (New Jersey, 1986)

Final Report of The New Mexico State Bar Task Force on WoMEN AND THe Legal Profession (New Mexico, 1990)

RePort of THE NeW York TASK Force on WOMEN IN THE COURTS (New York, 1986) 
Final RePort of THE RHODE ISLAND COMMITTEe ON WOMEN IN THE COURTS: A REPORT ON GENDER BIAS (Rhode Island, 1987)

UTAH TASK ForCE ON GENDER AND JUSTICE, REPORT TO THE UTAH JUDICIAL COUNCIL (Utah, 1990)

GENDER AND JUSTICE, REPORT OF THE VERMONT TASK FORCE ON GENDER BIAS IN THE LEGal SySTEM (Vermont, 1991)

Final Report of the Washington State Task Force on Gender AND JUSTICE IN THE COURTS (Washington, 1989)

Wisconsin Equal Justice Task Force: Final Report (Wisconsin, 1991) 